\title{
Bibliography of Getzel Cohen
}

1972

G. M. Cohen, The Hellenistic Military Colony: A Herodian Example, in: TransactAmPhilAss 103, 1972, 83-95.

1973

C. G. Boulter, D. W. Bradeen, A. Cameron, J. L. Caskey, A. J Christopherson, G. M. Cohen, and P. Topping (eds.), Lectures in Memory of Louise Taft Semple: Second Series, 1966-1970, [Norman] 1973.

G. M. Cohen, The Marriage of Lysimacus and Nicaea, in: Historia 22, 1973, 354-356.

1974

G. M. Cohen, The Diadochoi and the New Monarchies, in: Athenaeum 52, 1974, 177-179.

1978

G. M. Cohen, The Seleucid Colonies: Studies in Founding, Organization and Administration, Wiesbaden 1978.

1983

G. M. Cohen, Colonization and Population Transfer, in: E. van't Dack, P. van Dessel, and W. van Gucht (eds.), Egypt and the Hellenistic World: Proceedings of the International Colloquium, Leuven, 24-26 May, 1982, Leuven 1983, 63-74.

1984

G. M. Cohen, Property Rights of Hellenistic Colonists, in: J. Harmatta (ed.), Actes du VII Congrès de la Fédération Internationale des Associations d'Études Classiques 1, Budapest 1984, 323-325.

1989

E. van't Dack, W. Clarysse, G. Cohen, J. Quaegebeur, and J. K. Winnicki, The Judea-SyrianEgyptian Conflict of 103-101 B. C.: A Multilingual Dossier Concerning a "War of Scepters", Brussels 1989.

1991

G. M. Cohen, Katoikiai, Katoikoi and Macedonians in Asia Minor, in: AncSoc 22, 1991, 41-50.

1994

G. M. Cohen, The 'Antiochenes in Jerusalem'. Again, in: J. C. Reeves and J. Kampen (eds.), Pursuing the Text: Studies in Honor of Ben Zion Wacholder on the Occasion of his Seventieth Birthday, Sheffield 1994, 243-259.

1995

G. M. Cohen, The Hellenistic Settlements in Europe, the Islands, and Asia Minor, Berkeley 1995. 
1996

G. M. Cohen, A Dedication to the Samothracian Gods, in: StTroica 6, 1996, 201-207.

1998

G. M. Cohen, The Letters IAAG on Some Coins of Abila and Gadara, in: AmJNum 10, 1998, 95-101.

2001

G. M. Cohen, Soteira and Hekatompylos: Nicknames or Toponyms, in: J. L. Warner (ed.), Cultural Horizons 1: A Festschrift in Honor of Talat S. Halman, Syracuse 2001, 83-85.

2002

G. M. Cohen, Alexandreian, in: R. Aslan, S. Blum, G. Kastl, F. Schweizer, and D. Thumm (eds.), Mauerschau: Festschrift für Manfred Korfmann 3, Remshalden-Grumbach 2002, 1065-1074.

2004

G. M. Cohen and M. S. Joukowsky (eds.), Breaking Ground: Pioneering Women Archaeologists, [Ann Arbor] 2004.

2006

G. M. Cohen, The Hellenistic Settlements in Syria, the Red Sea Basin, and North Africa, Berkeley 2006.

2013

G. M. Cohen, Foundations (Hellenistic), in: EncAncHist 5, 2013, 2750-2752.

2013

G. M. Cohen, The Hellenistic Settlements in the East from Armenia and Mesopotamia to Bactria and India, Berkeley 2013.

2014

G. M. Cohen, How Cincinnati Returned to Troy, in: E. Pernicka, C. B. Rose, and P. Jablonka (eds.), Troja 1987-2012: Grabungen und Forschungen 1: Forschungsgeschichte, Methoden und Landschaft, Bonn 2014, 142-157.

2015

G. M. Cohen, Travel between Palestine and Mesopotamia during the Hellenistic and Roman Periods: A Preliminary Study, in: M. J. Geller (ed.), The Archaeology and Material Culture of the Babylonian Talmud, Leiden 2015, 186-224. 
